\title{
Hegumenia Ana (Adžić) - the Personification of Devotion
}

\section{A Collection of Works on the Occasion of 120 Years Since Her Birth and 70 Years Since Her Receiving of the Monastic Rank}

Dejan Tanić

Historical Archive “Srednje Pomoravlje, Jagodina info@arhivja.org.rs

Ilijana R. Čutura and Oliver Đorđević, eds. Hegumenia Ana (Adžić) - the Personification of Devotion: A Collection of Works on the Occasion of 120 Years Since Her Birth and 70 Years Since Her Receiving of the Monastic Rank. Jagodina: Faculty of Pedagogical Sciences at the University of Kragujevac Historical Archive “Srednje Pomoravlje," 2019, 171 pp.

This collection of works represents the basic overview of the most important moments in the secular (educational and artistic) and monastic life of Nadežda Adžić, the later Hegumenia Ana. The collection consists of 13 works, each of which presents interesting, important, and inspiring stories, that is, they illuminate all important parts of the rich life mosaic of one of the most important Serbian churchwomen of recent times.

This publication is available online on the website of the Faculty of Pedagogical Sciences at the University of Kragujevac, Jagodina: https://pefja.kg.ac.rs/zbornik-ana-adzic/. 


\section{Игуманија Ана (Аџић) - оличење посвећености}

\section{Зборник радова поводом 120 година од рођења и 70 година од примања монашког чина}

Дејан Танић

Историјски архив „Средње Поморавље“, Јагодина

Илијана Р. Чутура и Оливер Ђорђевић, ур. Иіуманија Ана (Аиић) - оличене йосвећеносиии: зборник раяова йоводом 120 іолина оg рођеньа и 70 іолина og йримана монашкої чина. Јагодина: Факултет педагошких наука Универзитета у Крагујевцу - Историјски архив „Средње Поморавље“, 2019. 171 стр. ; фотогр. ; 23 cm. ISBN 978-86-7604-184-8.

Доступно онлајн на вебсајту Факултета педагошких наука Универзитета у Крагујевцу, Јагодина: https://pefja.kg.ac.rs/zbornik-ana-adzic/.

У свеукупној српској историји, не само војној и политичкој, већ и економској, друштвеној, културној и религијској, свакако није било тежег, значајнијег и преломнијег историјског и цивилизацијског периода, од бурног 20. века. Након великих страдања и искушења, током Балканских ратова и Првог светског рата 1912-1918, српски народ и српско друштво, у целини, ушли су у процес (не)очекиване, убрзане и суштински важне, свеобухватне, трансформације. Настала је једна сасвим нова ( $y$ сваком йоїлеgy), географски много већа, сложенија, геополитички значајнија (у односу на претходну српску државу), мултинационална и мултиконфесионална држава - Кратьевина СХС (Јуїославија).

Само постојање Срба, као ујеgинииеельке наиије, и њено основно позиционирање, у оквиру такве сложене држа- 
ве, поставило је пред српски народ и целокупну структуру његовог друштва, нове, озбиљне изазове у свим даљим историјским и цивилизацијским, а нарочито духовно-религијским процесима. Улога Српске Православне Цркве, а нарочито српског монаштва, постала је пресудна за очување основног националноі и gуховноі идентитета, који је у појединим (нарочито -

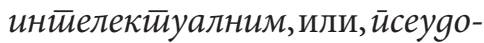
инйелекйуалним) круговима и сегментима друштва, почео да лута између Срйсйва и Jуїословенстива. У периоду између два светска рата, дошло је до значајне ревитализације православног (посебно женскої) монаштва, као природне, спонтане и (не)свесне одбрамбене реакције српског

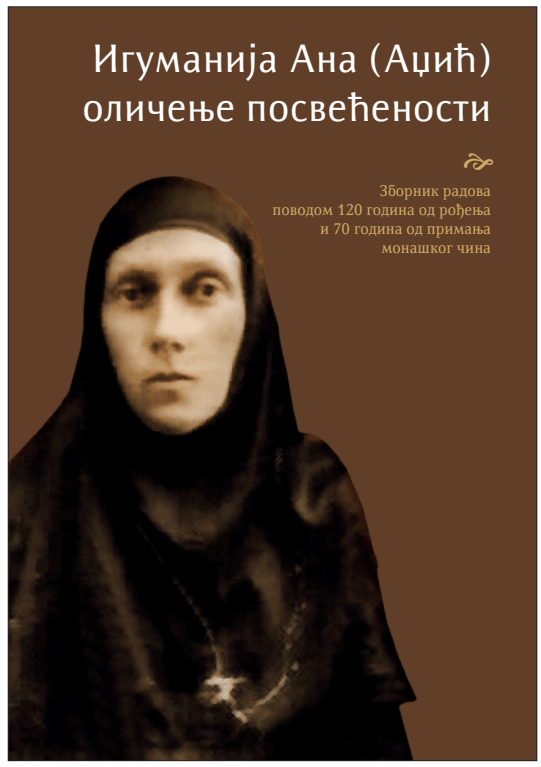
духовништва на све потенцијалне и реалне, културолошкорелигијске, па чак и политичке, претње и изазове, настале у разним ситуацијама и веома сложеним условима постојања ширег, мултиконфесионалног друштва, оптерећеног многим, разнородним, унутрашњим противречностима, какво је било југословенско.

Наредно велико искушење, наступило је током (19411945) и након Другог светског рата у Југославији, када су левичарско-атеистички наративи и системи вредности, постали део силом наметнутог кулйуролошкої и gрушйвено-

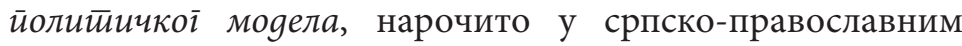
срединама. Тада се већ није постављало питање неког континуитета и будућег квалитативног развоја срӣскої

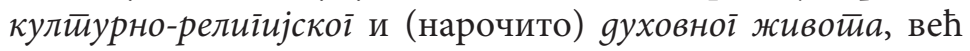
самог његовог опстанка. У тим временима, српско духов- 


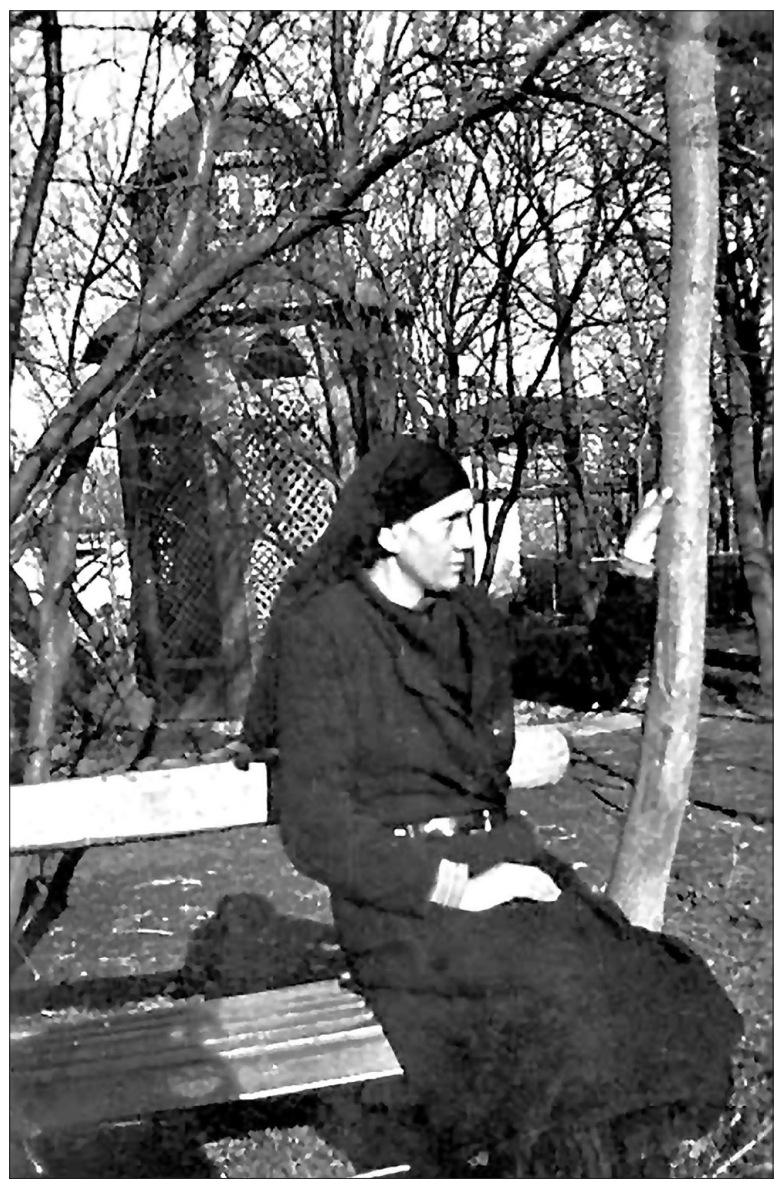

Fig. 1. Sister Nadežda Adžić in Bitola, around 1936

Сл. 1. Сестра Надежда Аџић у Битољу, око 1936. г.

ништво (и свештенство - у целини), поднело је огроман терет одржања суштинске структуре српске православне цивилизације. Улога игуманије манастира Враћевшнице, монахиғе Ане (рођене као Наgежgа, 1900. године у Београду), у овом тешком и захтевном, духовно-културолошком процесу, била је неизмерна. 


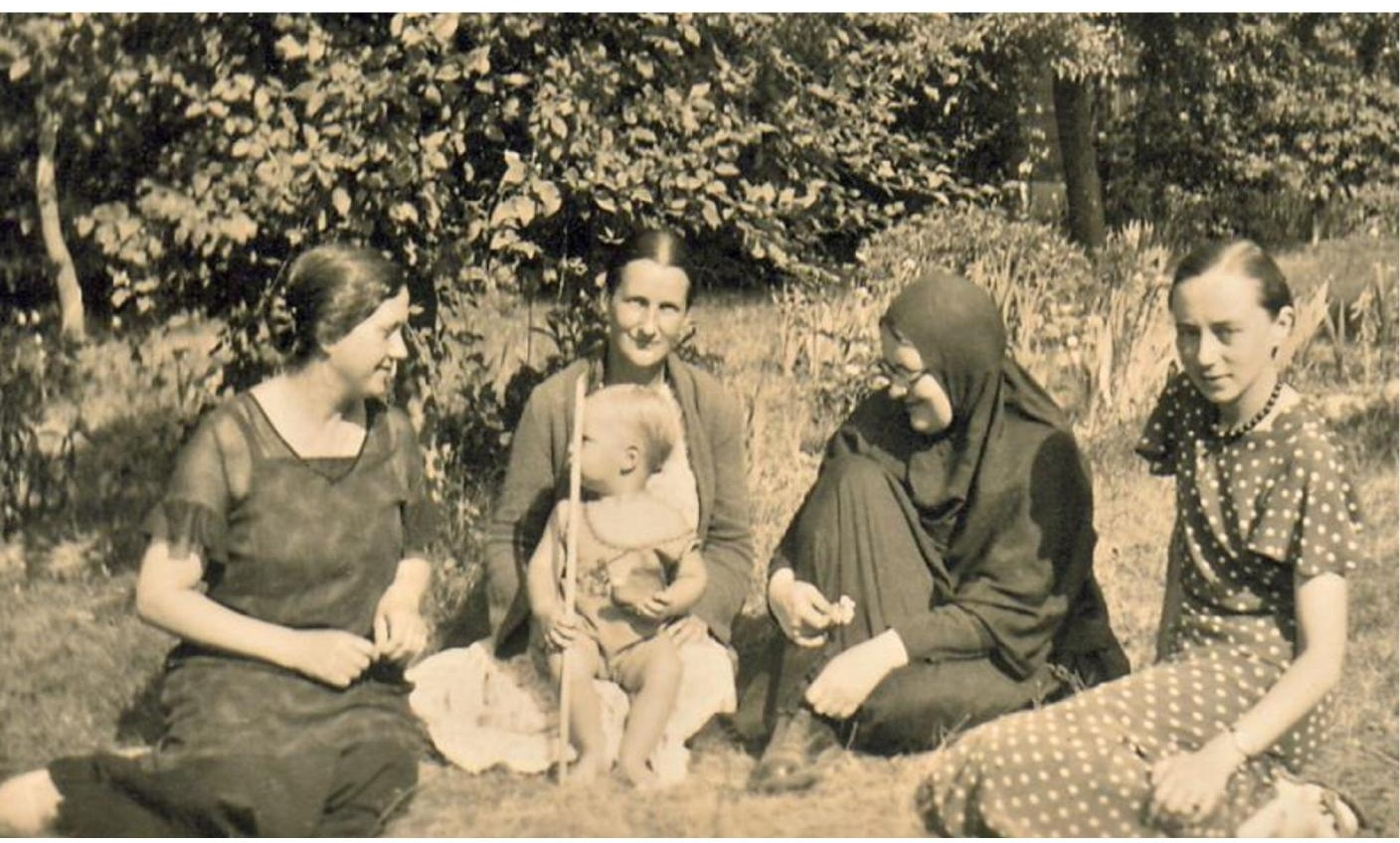

Fig. 2. Nadežda Adžić, Maria Zernov and Maria Skobtsova around 1933

Сл. 2. Надежда Аџић, Марија Зернов и Марија Скобцова, око 1933. г.

У складу са својом породичном традицијом (као кћер Сретена Аџића, оснивача Мушке учитељске школе у Јагодини), Надежда Аџић одабрала је просвету и уметност, као своја опредељења у световном животу. Међутим, током свог живота и рада у Београду, између два светска рата, често је била у контакту (на окупљањима - кружоцима, интелектуалаца и уметника) са многим значајним тадашњим, српским, али и руским (белоемигрантским) интелектуалцима и духовницима. Увидевши дубоки и пресудни значај вере и gуховнос $\bar{u} u$, за сваки облик живота и деловања (свакодневни и мисаони), Надежда Аџић подстакла је у себи основни импулс каснијег опредељења за духовни живот и монашку мисију. 
Овај зборник радова представља основни пресек најважнијих момената у световном (просветно-уметничком) и монашком животу Надежде Аџић, потоње игуманије Ане. Зборник се састоји од 13 радова, који, сваки за себе, представљају занимљиве, важне и инспиративне приче, односно, осветљавају све значајне делове богатог животног мозаика једне од најзначајнијих српских духовница новијег времена. Тематски, радови се могу поделити у три основне групе:

1) радове који анализирају све значајне околности, моменте и утицаје (у непосредном окружењу, али и много шире), током времена, који су постепено градили пут ка започињању Надеждиног (Аниног) монашког живота. Овде су нарочито значајни моменти интелектуално-духовног прожимања Надежде Аџић и знамените руске интелектуалне породице Зернов, као и утицај једног од највећих српских и православних духовника у историји - Ейискойа Николаја Велимировића;

2) радове који представљају и анализирају њен просветно-уметнички живот, као својеврсно предворје будућег монашког опредељења, и

3) радове који истичу сав значај, хуманост, духовно богатство и племенитост монашког живота и рада игуманије Ане.

Кроз свеукупан (световни и духовни) животни пут игуманије Ане, јасно се одсликава пресек једне изузетно важне, можда и преломне, етапе у развоју свих посебности срйске иравославне иивилизације. Основни циљ састављања и објављивања овог Зборника, заправо и јесте покушај да се сагледа и представи кључни део српске цивилизацијске вертикале, у којој је игуманија Ана била један од духовних светионика. 